\title{
How yeast cell wall components can alleviate mycotoxicosis in animal production and improve the safety of edible animal products*
}

\author{
J.-P. Jouany ${ }^{1,3}$, A. Yiannikouris ${ }^{1,2}$ and G. Bertin ${ }^{2}$ \\ ${ }^{1} I N R A$, URH-DIMA, Research Centre of Clermont-Theix \\ 63122 St. Genes Champanelle, France \\ ${ }^{2}$ Alltech-France, 2-4 avenue du 6 juin 1944, 95190 Goussainville,France
}

\begin{abstract}
Several authors have reported that the addition of yeast cell walls to contaminated feeds alleviates the harmful effects of mycotoxins, but nothing is known on the chemical interactions between the binder and the toxins.

We showed that $\beta$-D-glucans are the yeast component responsible for the complexation of mycotoxins, and that the reticular organization of $\beta$-D-glucans and the distribution between $\beta-(1,3)$ D-glucans and $\beta-(1,6)$-D-glucans play a major role in the efficacy. Weak hydrogen and van der Waals bonds are involved in the complexation of mycotoxins by $\beta$-D-glucans, thus indicating that the chemical interaction is more of "adsorption type" than "binding type". We performed molecular modelling and calculated potential energy to estimate the stability of the complexes.
\end{abstract}

KEY WORDS: mycotoxins, binders, yeast cell wall, $\beta$-D-glucans, animal production

\section{INTRODUCTION}

Mycotoxins are secondary metabolites produced by various moulds such as Aspergillus, Penicillium and Fusarium (Table 1). Fungal contamination of plants can occur in the field during growth, or at transport and storage in certain environmental conditions. Detectable levels of nearly 300 potentially toxic metabolites secreted by moulds contaminate between 25 and $40 \%$ of cereals

\footnotetext{
* This work was done during the $\mathrm{PhD}$. Thesis of Alexandros Yiannikouris, which was supervised by Dr J.-P. Jouany

${ }^{3}$ Corresponding author: e-mail: jouany@clermont.inra.fr
} 
Table 1. Molds and associated mycotoxins

\begin{tabular}{ll}
\hline Molds & Mycotoxins \\
\hline $\begin{array}{l}\text { Aspergillus flavus, A. parasiticus, } \\
\text { A. nomius }\end{array}$ & Aflatoxins B1, B2, G1, G2
\end{tabular}

Penicillium verrucosum,

Aspergillus clavatus, A. Ochraceus

Penicillium expansum, P. urticae, Aspergillus clavatus, Byssochlamys nivea

Fusarium sporotrichioides,

F. graminearum, F. culmorum,

F. poae, F. roseum, F. tricinctum,

F. acuminatum

Fusarium moniliforme,

F. proliferatum

Ochratoxin A

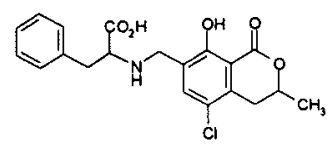

Patulin

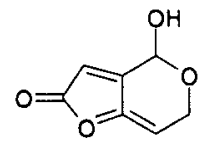

Trichothecenes (Deoxynivalénol)

Fumonisins B1, B2, B3

(FB1)<smiles>CC1=CC2OC3CC4(CC(O)C4(CO)C3O)C(O)C2C(=O)C1=O</smiles>

Zearalenone

Fusarium graminearum,

F. culmorum,

F. crookwellense

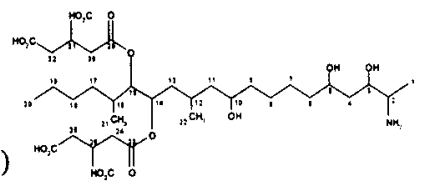

F. moniliforme, F. crookwellense,

F. subglutinans, F. sambucinum,

F. napiforme, F. heterosporum,

F. oxysporum, F. solani,

F. proliferatum

Fusaric acid
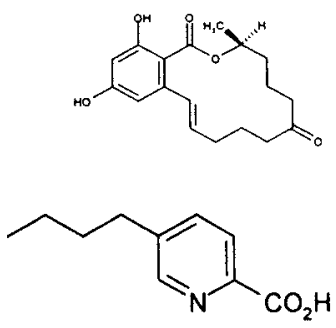

and cereal derivatives worldwide, as well as fruits, spices, coffee and many other ingredients (Figure 1). The ingestion of contaminated feeds and foods then induces deleterious effects in animals and humans.

Despite recent crises (bovine spongiform encephalitis, listeriosis, salmonellosis, dioxin contamination, etc.) in animal production, consumers are still largely unaware of the risks associated with the natural presence of toxins or their metabolites in food and feed consumed by humans and animals (Guerre et al., 2000). Since these toxins are of natural origin, people generally believe that they do not carry risks. In fact, mycotoxins can be hepatotoxic, haematotoxic, nephrotoxic, immunotoxic, neurotoxic, mutagenic, genotoxic, reprotoxic, teratogenic and carcinogenic. Furthermore, multiple 
contaminations often result in synergy, increasing the dangerousness of individual mycotoxins. They can cause numerous disorders and diseases, which sometimes prove to be fatal in animals (Pfohl-Leszkowicz, 2000) or humans (Krishnamachari et al., 1977; CAST, 2003), which is a clear indication of the potential danger associated with mycotoxins. This risk has existed from the origin of organized agricultural practices (Pittet, 1998). For example, the Old Testament makes reference to ergotism (Schoental, 1984) and indirectly attributes the decline of the Etruscan civilization to the T-2 toxin and (or) zearalenone (Schoental, 1991). The first modern mycotoxicosis due to aflatoxins was reported in the 1960s following the death of 100,000 turkeys reared in Great Britain from liver necrosis and biliary hyperplasia. Fortunately, this kind of acute toxicosis, which is easy to detect, remains rare. However, chronic toxicoses due to ingestion of low amounts of contaminated feeds over long periods are more common, and also more difficult to detect.

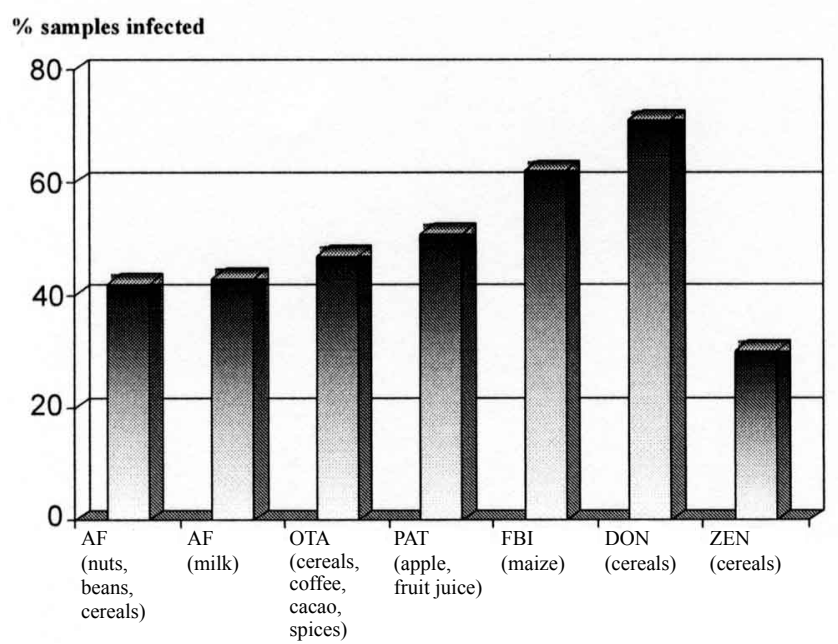

Figure 1. Recent data on the occurrence of mycotoxins in feed (from Pittet, 1998)

An effective control of mycotoxin contamination of feed requires an integrated strategy "from the field to the fork". Thus, mould growth and mycotoxin production can be controlled at field level by using resistant crops and by crop rotation; during plant growth by applying good agricultural practices and appropriate pesticides/ insecticides; during harvest by avoiding physical damage and over-contamination and by eliminating damaged grains; by controlling the level of contamination and environmental factors; by using adapted preservatives during storage and applying physical, chemical or biological decontamination procedures after storage; and by avoiding damage to grains during distribution and processing. These preventive measures may limit contamination levels in feed and food for both animals and 
humans, and thereby the presence of toxic residues in edible animal products such as milk, meat and eggs. However, it is impossible to totally eliminate fungi and mycotoxins (CAST, 2003). Strategies based on sorting (Jemmali, 1990; Pasikatan and Dowell, 2001) and/or destruction of contaminated foods (Scott, 1998; Karlovsky, 1999) are not realistic, given the costs involved. Furthermore, dilution of contaminated feed to decrease the level of contamination until it falls below the authorized levels is forbidden in Europe since July 2003.

\section{THE GENERAL EFFECT OF MYCOTOXIN BINDERS}

Due to the lack of practical solutions to totally preclude mycotoxin contamination in feeds, binders have been proposed to sequestrate the toxins and prevent them from being absorbed in the animal's digestive tract, thereby limiting their effect on animals and thus their transfer to edible animal products.

Inorganic materials such as clays, bentonites and aluminosilicates, known for their adsorptive properties, were originally proposed to suppress the toxic effect of aflatoxins (Patterson and Young, 1993; Ramos and Hernandez, 1997; Grant and Phillips, 1998; Galvano et al., 2001; Huwig et al., 2001; Lemke et al., 2001), but they have limited efficacy against other toxins. Furthermore, they have to be incorporated at high levels in order to be efficient, thus reducing the nutritional value of animal diets. They also reduce the biological value of certain nutrients, and may contain dioxins and heavy metals. This is why during the last decade, other types of binders have been studied. Among them, organic compounds such as yeast cell walls (Devegowda et al., 1998a,b; Newman, 2000; Dawson et al., 2001; Freimund et al., 2003) have been proposed as an alternative solution to bind several mycotoxins without impairing nutrient bioavailability or inducing detrimental environmental effects. All these studies have tested the efficacy of yeast cell wall through performance levels or through more specific biomarkers in blood, urine or milk of animals fed with naturally contaminated feed or feed supplemented with pure mycotoxins and supplied or not with the binder (Devegowda et al., 1998a; Whitlow and Hagler, 1999, 2002; Newman, 2000; Whitlow et al., 2000; Dvorska and Surai, 2001; Smith et al., 2001, 2002; Surai et al., 2002; Swamy et al., 2002a,b; Dvorska, 2003; Dvorska et al., 2003). However, few studies have investigated the mechanisms underlying the in vitro formation of chemical complexes between toxins and yeast cell wall components (Dawson et al., 2001; Diaz et al., 2002). Recent studies carried out on inorganic binders have focused on the chemical aspects of the binding process. Most of these analytical studies have been carried out on aluminosilicate clays. They consisted in drawing the adsorption curves and modeling them to determine physical factors such as adsorption capacity, number of sites involved in the binding process, strength of the interaction between binder and 
mycotoxin, as well as certain thermodynamic parameters (Grant and Phillips, 1998; Lemke et al., 2001). This research effort has led to several hypotheses on the nature of the complexes formed between yeast cell walls and certain mycotoxins, and possible hydrophobic interactions have been suggested for zearalenone (Freimund et al., 2003). However, none of these studies have described the chemical mechanisms of the complex-forming activity at the molecular level.

\section{STUDY OF THE CHEMICAL MECHANISMS OF MYCOTOXIN COMPLE- XATION BY YEAST CELL WALLS}

The chemical structure of yeast cell wall

Several authors have identified the cell wall as the yeast fraction involved in the mycotoxin sequestration process (Devegowda et al., 1998a,b; Dawson et al., 2001), but very little is known on the chemical interactions between the binder and the toxins. To better explain our scientific approach, further information on the chemical structure of yeast cell walls is given below.
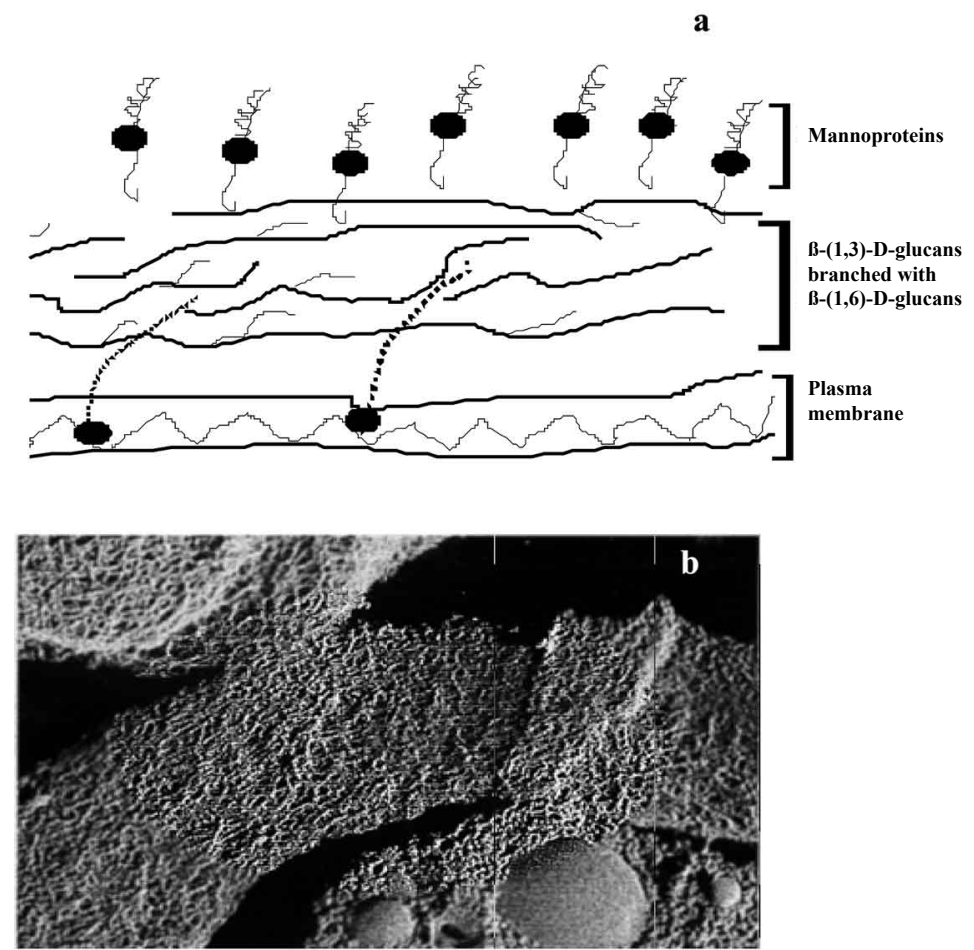

Figure 2. a. Schema of the chemical organization of the cell wall of Saccharomyces cerevisiae. b. Scanning microscopy of yeast wall 
The cell wall fraction of Saccharomyces cerevisiae, which is mainly composed of polysaccharides ( 80 to $90 \%$ ), makes up 15 to $30 \%$ of the dry weight of the whole cell. The mechanical strength of the cell wall is mainly due to an inner layer composed of $\beta$-D-glucan chains (50 to $60 \%$ of the wall's dry weight), which consist in $\beta$-(1,3)-D-glucans with high complexity and degree of polymerization $(2 \mathrm{kDa}$ for soluble forms; up to $35 \mathrm{kDa}$ for insoluble forms) (Lee, 2002), branched with linear side chains of $\beta-(1,6)$-D-glucans with a low degree of polymerization (Figure 2). $\beta$-D-glucans can be found either under random coils or under more organized conformations arranged in a kind of network composed of single helix chains, which are associated in a more or less densely-packed triple helix and stabilized by interor intra-hydrogen bounds (Kogan, 2000). This fraction is firmly bound to the plasma membrane through linear chitin chains made of around ninety $\mathrm{N}$-acetylglucosamine units. Chitin contributes to the insolubility of the overall structure and the packing of $\beta$-D-glucans, which both influence the plasticity of the cell wall. Chitin molecules make up 2 to $4 \%$ of the polysaccharides in the cell wall, and up to $10 \%$ in some mutant laboratory strains. The outer layer of the yeast cell wall is made of mannoproteins, which play a major role in the exchanges with the outside medium and environment of yeasts. Mannans (over 150 units of D-mannose) are linked to $\beta$-D-glucans via a GPI anchor where the proteins are located at the external part of cell walls (Lipke and Ovalle, 1998). This structure is highly dynamic and can vary according to the yeast strain, since about 1200 genes drive the synthesis of these cell wall components. Culture conditions including $\mathrm{pH}$, temperature, oxygenation rate, nature of the medium, and concentration or nature of the carbon source strongly modulate the quantity and structural properties of $\beta$-D-glucans, mannans and chitin in cell walls. Moreover, the cell cycle stage also interacts with the cell wall composition. For example, budding induces strong changes in the distribution of the structural components of the cell wall such as chitin.

\section{Our research strategy}

The main goals of this study were 1 . to identify the cell wall components responsible for the complexation of mycotoxins and 2. to characterize the chemical bonds involved in the chemical interactions between yeast cell wall components and mycotoxins. Most of our studies were carried out on zearalenone (ZEN), which was used as a mycotoxin model since it has a good balance between polar and hydrophobic groups, harbours a benzene and a non-benzene cycle and has an average molecular size (molecular weight $=318$ ).

Our research program comprised the following steps: (1) set up an in vitro method to quantify the capacity of binders to form strong complexes with mycotoxins through some physical constants calculated from modelling of binding curves. This method has been applied to the whole cell wall isolated 
from various yeast strains, to each component of the fractionated cell wall, and to pure components used as models of cell wall components; (2) use spectroscopic techniques (NMR, UV spectroscopy, X-ray diffraction) to assess the chemical interactions between the binder and mycotoxins at the macromolecular level; (3) perform in silico analysis (molecular mechanics) of both the toxin and the binder molecules, separately, with the aim of constructing 3D-models of the molecular interactions between the two molecules. Following these steps, the most stable complexes were assessed by using their lowest potential energy an indicator of the entropy of the pair-molecule system. The nature of the chemical bonds within complexes was also tested in the models.

\section{MATERIAL AND METHODS}

\section{Production of yeast biomass}

Four strains of $S$. cerevisiae, the wild type wt292, the fks 1 mutant type, the mnn9 mutant type and sc1026 were obtained from INRA and Alltech Inc. (KY, USA) and cultured in flasks containing a YPD medium ( $1 \%(\mathrm{w} / \mathrm{v})$ yeast extract, $2 \%$ $(\mathrm{w} / \mathrm{v})$ bacteriological peptone and $2 \%(\mathrm{w} / \mathrm{v})$ glucose) at $+30^{\circ} \mathrm{C}$, shaken at $200 \mathrm{rpm}$. Cultures were stopped when the concentration reached $2 \times 10^{7}$ cells $/ \mathrm{mL}$.

\section{Isolation and chemical analysis of yeast cell walls}

Cell walls were disrupted with glass beads and isolated (Dallies et al., 1998). Quantification of mannans and glucans was achieved by mannose and glucose analysis after $2 \mathrm{~N}-\mathrm{H}_{2} \mathrm{SO}_{4}$ hydrolysis at $+100^{\circ} \mathrm{C}$ for $4 \mathrm{~h}$. An enzymatic method was used to determine the chitin content (Popolo et al., 1997).

\section{Alkali extraction of yeast cell wall components}

Cell walls were fractionated by alkali extraction with $1 \mathrm{M}-\mathrm{NaOH}$ and $0.5 \%$ of $\mathrm{NaBH}_{4}$ for $24 \mathrm{~h}$ at $+37^{\circ} \mathrm{C}$ under agitation (Catley, 1988; Fleet, 1991). The suspension was centrifuged $(10,000 \mathrm{~g}$ for $5 \mathrm{~min})$ and the supernatant and pellet fractions were separated. Supernatants were dialysed $(1: 100, \mathrm{v} / \mathrm{v})$ on cellulose-ester membranes (MWCO: 6 to 8,000) with $0.02 \mathrm{M}$ Tris/ $\mathrm{HCl}$ buffer ( $\mathrm{pH} 7.4$ ) for $16 \mathrm{~h}$ at $+4^{\circ} \mathrm{C}$ with magnetic stirring. $\beta$-D-glucans were separated from mannans using a concanavalin A sepharose column and eluted with $0.02 \mathrm{M}$ Tris/ $\mathrm{HCl}$ buffer (pH 7.4) and $0.5 \mathrm{M} \mathrm{NaCl}$, and stored at $-20^{\circ} \mathrm{C}$ until use. The pellets were washed thoroughly with $1 \mathrm{~mL}$ of $75 \%$ ethanol/10 mM Hepes buffer $(\mathrm{pH} 7.1)$, suspended in $2 \mathrm{~mL}$ of $0.1 \mathrm{M}$ Tris/ $\mathrm{HCl}$ buffer ( $\mathrm{pH} 8.5$ ), and stored at $-20^{\circ} \mathrm{C}$ until use. 


\section{Quantitative analysis of carbohydrates}

Analyses were performed in triplicate on a Dionex Bio-LC system (Sunnyvale, CA) with a pulsed amperometric detector equipped with a gold electrode. Separation of carbohydrates was performed on a CarboPac PA1 anion-exchange column $(4 \times 250 \mathrm{~mm})$ equipped with a guard column. Elution was performed at a flow rate of $1 \mathrm{~mL} / \mathrm{min}$ at $+20^{\circ} \mathrm{C}$ with $18 \mathrm{mM} \mathrm{NaOH}$.

\section{Mycotoxin quantification}

Mycotoxins were analysed by isocratic HPLC on a HP-1090 Series II HPLC (Hewlett-Packard Co.) using a UV diode array detector coupled to an HP-1046A fluorescence detector. A C18 Nucleosil Spherisorb ODS-2 column $(4 \times 150 \mathrm{~mm})$ equipped with a guard column was used at a flow rate of $0.8 \mathrm{~mL} / \mathrm{min}$ of mobile phase.

\section{In vitro technique to estimate binding capacity (Yiannikouris et al., 2003)}

For each in vitro test, $100 \mu \mathrm{g} / \mathrm{mL}$ of adsorbent were placed in tubes together with either $2,4,6,8,10$ or $20 \mu \mathrm{g} / \mathrm{mL}$ of ZEN dissolved in water and agitated at $200 \mathrm{rpm}$ for $1.5 \mathrm{~h}$ at $+37^{\circ} \mathrm{C}$. Control tubes with no adsorbent were used in parallel. Next, the suspension was centrifuged at $5,000 \mathrm{~g}$. The amount of bound toxin was calculated for each mycotoxin supplementation by subtracting the amount of free toxin found in the supernatant of the experimental tubes from the amount found in the control tubes with no adsorbent. DataFit 7.1 software (COakdale) was used to plot the experimental data, set up the regression curve (curve fitting) and calculate the statistical data (Yiannikouris et al., 2003) (Figure 3).

\section{Structural investigations through molecular modeling}

Molecular modeling was carried out on Silicon Graphics computers running Accelrys software packages (Accelrys. Inc, CA, USA) and InsightII, Biopolymer, Analysis, Docking and Discover modules. A CFF91 force field adapted to "polysaccharide/binder" interaction studies was used under vacuum $(\varepsilon=1)$. Construction of the most highly probable conformations of $\beta-(1,3)$-Dglucan chains was performed as described in a previous study (Yiannikouris et al., 2004a). $[\varphi, \psi]$ dihedral angle values of a $\beta-(1,3)$ - bond between two glucoses were explored through their rotation (from $-180^{\circ}$ to $+180^{\circ}$ ) and their minimum energy conformations evaluated before further elongation to a 5,868 Da polymer. $\beta$-D-glucan structure was assessed using $\mathrm{X}$-ray diffraction under several hydration levels (Yiannikouris et al., 2004a) in order to identify the influence on the packing of yeast cell wall components (Nuessli et al., 2003). 


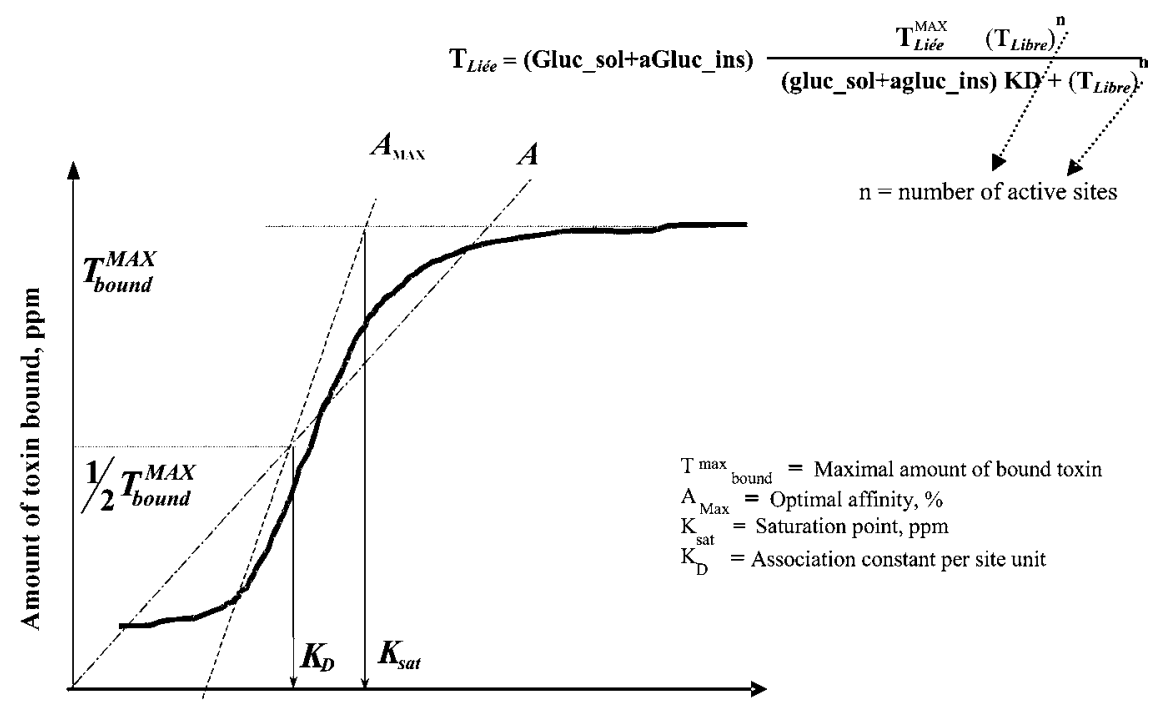

Amount of total toxin added in the medium, ppm

Figure 3. Modeling of an adsorption curve and physical parameters calculated from Hill's model

Characterization of the chemical bonds between binder and mycotoxins (Yiannikouris et al., 2004a)

Fifty micrograms $/ \mathrm{mL}$ of ZEN and soluble purified $\beta$-D-glucans were mixed in $10 \mathrm{~mL}$ of a Milli- $\mathrm{Q}^{\text {uft }}$ water, shaken at $640 \mathrm{rpm}$ for $1.5 \mathrm{~h}$ at $+39^{\circ} \mathrm{C}$ and then cooled on a bath of 2-propanol kept at $-30^{\circ} \mathrm{C}$ before freeze-drying. The powder collected after freeze-drying contained the $[\beta-\mathrm{D}$-glucans $+\mathrm{ZEN}]$ complexes, which were solubilized in $500 \mu \mathrm{L}$ of DMSO- $\mathrm{d}_{6}$ to reach a concentration of $1 \mathrm{mg} / \mathrm{mL}$ for each molecule. The solution was analysed using an NMR Bruker Avance 400 spectrometer $(300 \mathrm{~K})$. The ${ }^{1} \mathrm{H}$ NMR spectra of the [ $\beta$-D-glucans + ZEN] sample were recorded and compared with the spectra of each of the two components.

Using in silico molecular mechanics investigations, the ZEN molecule was constructed from our NMR and X-ray data and from those obtained by Cordier et al. (1990). A [ZEN + $\beta$-D-glucans] complex was constructed by manually positioning ZEN molecules in cavities on the helix of the $\beta$-(1,3)-D-glucan polymer. Translations plus rotations as well as up and down positioning of ZEN were achieved inside the $\beta$-(1,3)-D-glucan to explore all the possible spatial orientations of the interaction within a 10,000 iterations minimization procedure. 


\section{RESULTS}

\section{Chemical composition of yeast cell wall}

The cell wall fraction accounted for $24.8,22.3,21.4$, and $13.2 \%$ of the dry weight of the total cell wall for wt292, fks1, mnn9 and sc 1026, respectively. It was composed of various glucans, mannans and chitin contents. Mannan/glucan ratios were $1.25,2.09,2.18$, and 0.21 in the cell walls of wt292, fks1, sc1026, and mnn9, respectively. Wt292 and mnn9 strains had high $\beta$-D-glucan contents, respectively 45 and $75 \%$ of the total cell wall, compared to fks1 and sc1026 strains $(\sim 30 \%)$. Both mnn9 and fks1 strains had high chitin contents, 9.7 and $5.8 \%$, respectively, while wt292 and sc1026 had only $\sim 2 \%$. Differences in the chemical composition of the cell walls among the tested strains were used to screen the cell wall component, which is chiefly involved in the binding process.

Mathematical approach for identifying the components involved in chemical interactions between mycotoxins and yeast cell walls

Curves representing the amount of bound toxin vs the amount of added toxin were plotted according Hill's model with n sites (HMN) (Figure 3), which improved the fit of our experimental data $\left(\mathrm{R}^{2}=0.993\right)$ compared to isothermal models or sigmoid models, which are generally used for inorganic adsorbents (Grant and Phillips, 1998). The adsorption efficacy of the cell wall fraction extracted from each S. cerevisiae strain on ZEN was calculated using Hill's

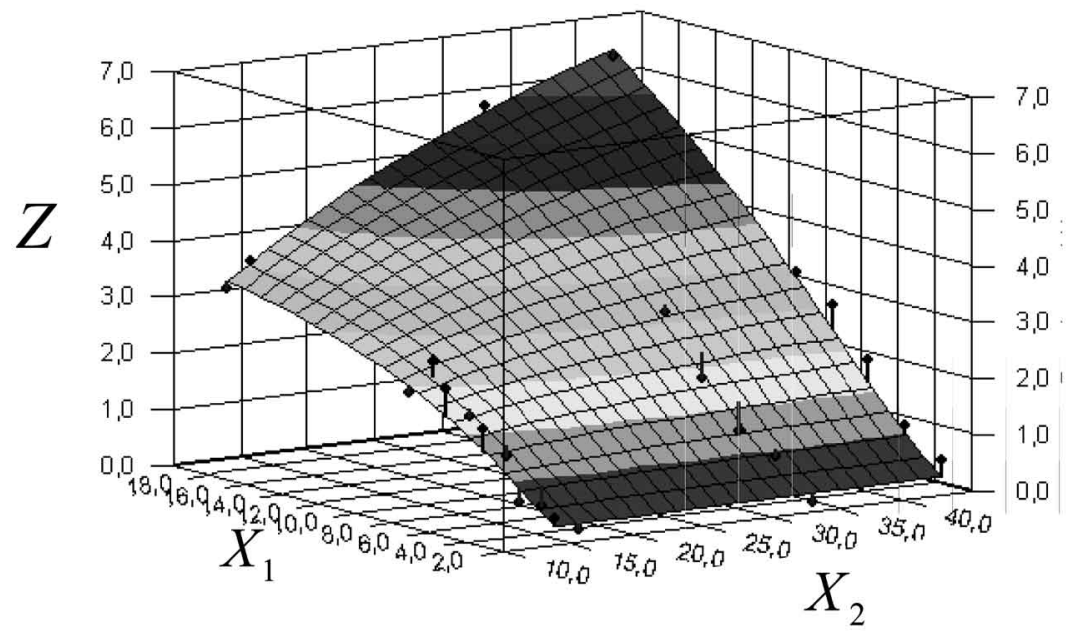

Figure 4. Influence of $\beta$-D-glucans on the absorption efficacy of yeast cell walls $\left(X_{1}\right.$ : amount of added mycotoxin; $\mathrm{X}_{2}$ : amount of $\beta$-D-glucans; $Z$ : amount of absorbed myxotoxin) 
model, which also discriminates the strains. The sigmoid shapes of the curve revealed a cooperative interaction between toxin and binder (Yiannikouris et al., 2003). HMN was used to set up three sub-models: 1. the HMN equation evaluated the ZEN adsorption efficacy of total cell wall, alkali-soluble and alkali-insoluble fractions from each strain of S. cerevisiae and was used to discriminate the strains; 2 . the HMN-2 equation took into account the amounts of total $\beta$-D-glucans in the cell wall and related them to the adsorption properties for ZEN (Yiannikouris et al., 2004b); 3. the HMN-3 equation took into account the respective amounts of alkali-insoluble and alkali-soluble fractions of $\beta$-Dglucans and their roles in the adsorption process (Yiannikouris et al., 2004c). Calculations of $A=T_{\text {bound }}^{M A X}$ (maximal amount of toxin bound) and $\mathrm{K}_{\mathrm{D}}$ (association constant) were used to evaluate the affinity rates (A) given in percentages as: $A=T_{\text {bound }}^{\text {MAX }} / 2 . K_{D^{\circ}}$.

\section{Identification of yeast cell wall component(s) involved in complex formation}

We found a correlation between the amount of $\beta$-D-glucans in cell walls and binding capacity $\left(\mathrm{R}^{2}=0.889 ; \mathrm{RSD}=0.534 \mu \mathrm{g} / \mathrm{mL} ; \mathrm{A} \approx 30 \%\right)$ (Figure 4 ). Cell walls of wt292 and mnn9 strains with higher levels of $\beta$-D-glucans were able to complex larger amounts of ZEN with higher affinity rates than the fks 1 and sc1026 strains. High chitin content in mnn9 and fks1 strains increased the insolubility of $\beta$-D-glucans and decreased the flexibility of the overall structure, which consequently limited the accessibility of ZEN to the chemical sites of the $\beta$-D-glucans. Thus, these strains had a lower binding capacity than expected from their $\beta$-D-glucan content (Yiannikouris et al., 2004b).

The alkali-insoluble fraction had a greater affinity (up to 50\%) than the alkalisoluble fraction (about 16\%). From the results obtained with each fraction or with HMN-3 equation, taking into account both fractions $\left(\mathrm{R}^{2}=0.969 ; \mathrm{RSD}=0.296 \mu \mathrm{g} /\right.$ $\mathrm{mL})$, we confirm that $\mathrm{mnn} 9$ and wt 292 strains $(\mathrm{A}=35.9$ and $50.4 \%$ for the alkaliinsoluble fractions, respectively) had the highest adsorption efficacy for ZEN. Partial elimination of chitin during alkali extraction led to a 1.5 -fold improvement in the capacity of the alkali-insoluble fraction of $\beta$-D-glucans in the mnn9 strain to adsorb ZEN compared to wt292 (Yiannikouris et al., 2004c).

Pure $\beta$-D-glucans such as laminarin, curdlan, pachyman and pustulan, which are made with various " $\beta-(1,3)$-D-glucan/ $\beta-(1,6)$-D-glucan" ratios were used to determine the individual role played by each of these $\beta$-D-glucans. $\beta$-(1,3)-Dglucans were responsible for the main complexing activity since they had greater affinity than $\beta-(1,6)$-D-glucans, but were less stable in extreme environmental conditions such as $\mathrm{pH}>8$. As a consequence, complexes obtained from binders made of $\beta$-(1,3)-D-glucans highly branched with $\beta$-(1,6)-D-glucans are less sensitive to alkaline $\mathrm{pH}$ than $\beta$-D-glucans made of pure chains of $\beta$-(1,3)-D- 
glucans. We can conclude that addition of branched $\beta$-(1,6)-D-glucans on $\beta$-(1,3)-D-glucans improves the stability of complexes prepared from ZEN.

Study of the chemical bonds involved in the interaction between B-D-glucans and ZEN

The alkali-insoluble $\beta$-D-glucans increase the rigidity of the yeast cell walls and make them more resistant to the external environment. $\beta$-D-glucans are defined as a complex 3D structure with alternating regions of random coil, single helices and triple helices (Lipke and Ovalle, 1998; Kogan, 2000). In contrast, yeast cell walls with high content of alkali-soluble $\beta$-D-glucans are more flexible (Kopecka et al., 1974; Fleet, 1991). As discussed previously, chitin encrustation into glucans increases their mechanical resistance and their rigidity.

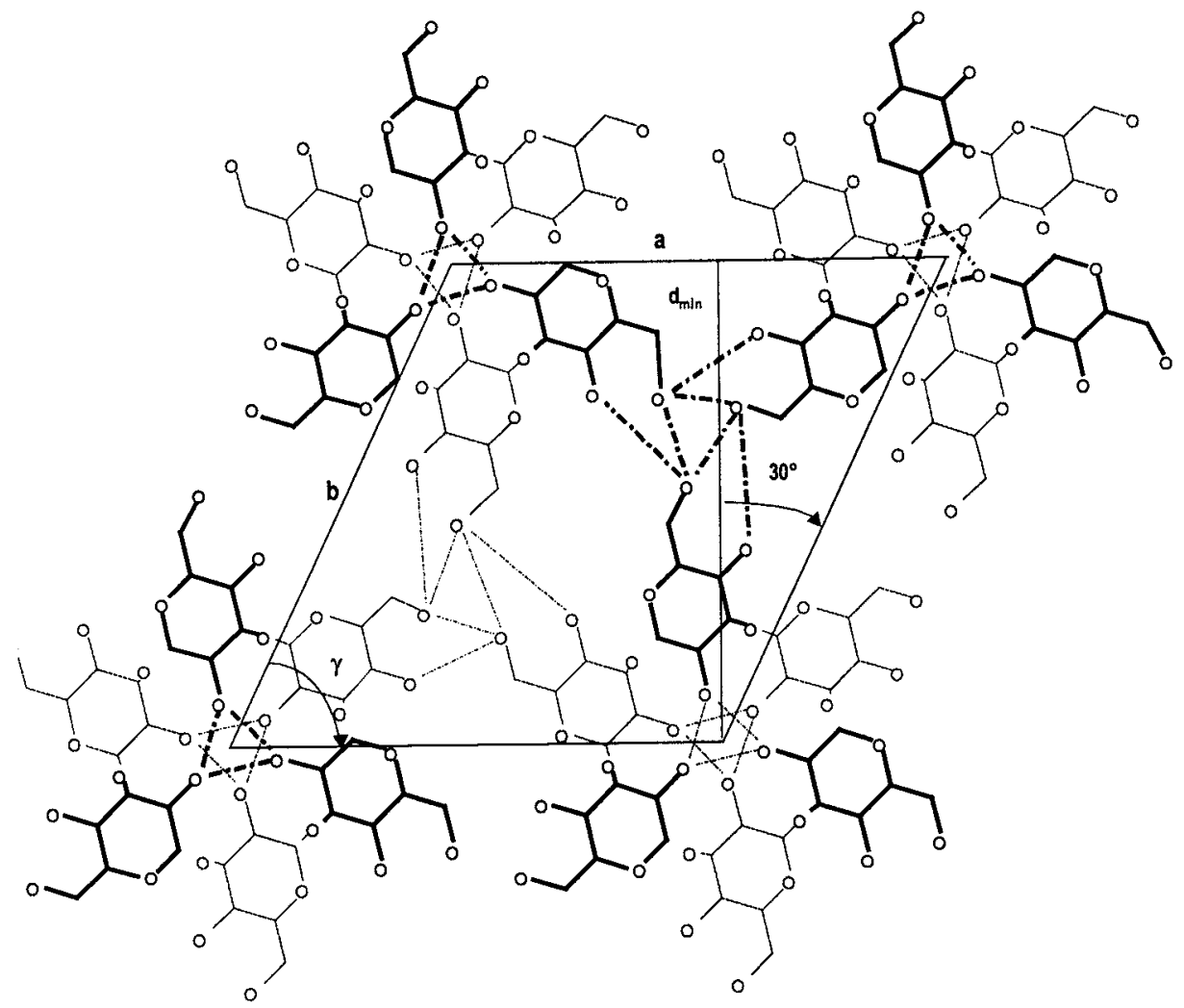

Figure 5. Diagram of the projection following "a" and "b" axes of the hexagonal crystal made of $4 \times$ (3 dimers of $\beta$-D-glucopyranose organized in triples helices) (Chuah et al., Pelosi, 2002). Glucopyranose residues in bold are forward to the plane "a-b" and the residues in grey are backward to the plane "a-b". Stabilization of the helix involved intra and inter-helical hydrogen bonds. Size of the diagram: $\mathrm{d}_{\min }=1.36 \mathrm{~mm} ; \mathrm{a}=\mathrm{b}=1.56 \mathrm{~nm}$; fibre period $\mathrm{c}=0.60 \mathrm{~nm} ; \gamma=120^{\circ}$ 
A wide-angle X-ray diffraction study carried out on purified fraction of $\beta$-D-glucans indicated that they are spatially organized as a cluster of four triplehelix chains of $\beta-(1,3)-D$-glucans (Chuah et al., 1983). These helical chains were $1.56 \mathrm{~nm}$ apart, with a fibre interval of $0.60 \mathrm{~nm}$, consequently defining six $\beta$-Dglucopyranose units per turn of helix (Figure 5). Such organization was assessed by the comparison of pure $\beta$-D-glucans such as paramylon, curdlan and laminarin, with reticular distances of 1.36 (Chuah et al., 1983), 1.50 and $1.62 \mathrm{~nm}$, respectively, as calculated during our X-ray diffraction measurements. The increase in reticular distance between $\beta$-D-glucan molecules involved an increase in the relaxation level of their triple helical conformation (Marchessault et al., 1977; Marchessault and Deslandes, 1979). For example, the laminarin molecule that was used for further investigations on the interaction with ZEN has a highly relaxed triplehelix and (or) single-helix organization as indicated by its high reticular distance. These conformations and different degrees of relaxation can be found together in the highly complex structure of $S$. cerevisiae cell wall. Molecular mechanics confirmed that the most stable conformation of the $\beta-(1,3)$-D-glucan single helical chain was found for glycosidic linkage of $[\varphi, \psi]=\left(-100^{\circ},+140^{\circ}\right)$ with six

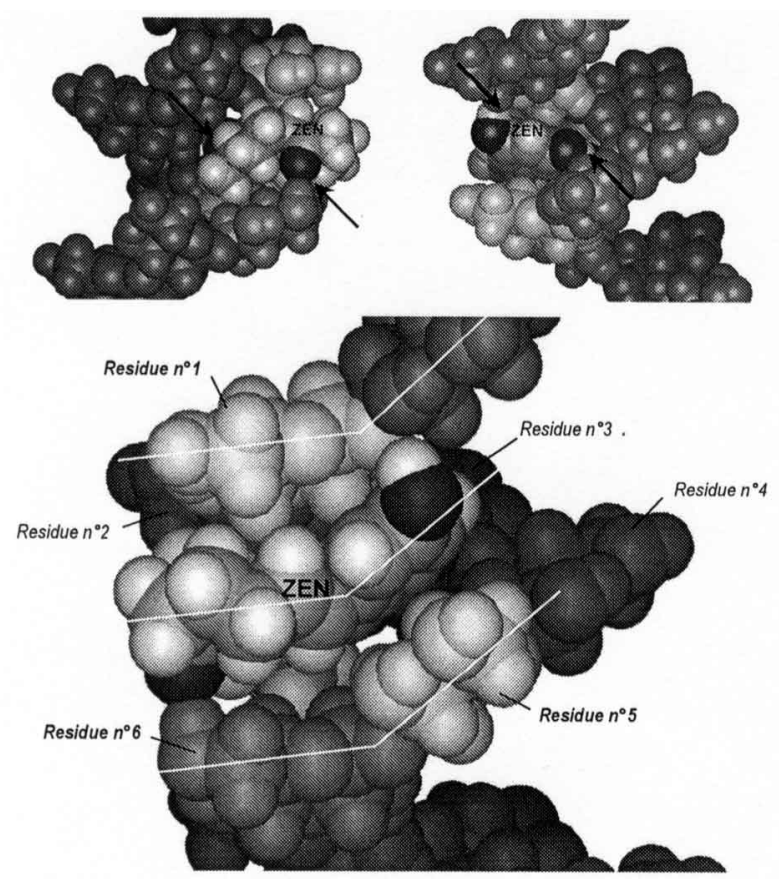

Figure 6. Computer-generated views (Insight II software) of the energy-minimized structure of the docking phenomenon of the most favourable conformation of ZEN into the single-helix of $\beta$ - $(1,3)$ D-glucan chain. Arrows indicate the hydrogen bonds involved in the interaction. Lines highlight the steric complementarity between ZEN and $\beta$-(1,3)-D-glucan geometry 
$\beta$-D-glucopyranose units per turn. Two distinct low-energy conformations of $\beta$ $(1,6)$-D-glucans were found for the dihedral angles $[\varphi, \psi, \omega]=\left(-87.7^{\circ} ;+179.9^{\circ}\right.$; $\left.-72.6^{\circ}\right)$ and $[\varphi, \psi, \omega]=\left(-85.5^{\circ} ;+179.7^{\circ} ;-177.9^{\circ}\right)$, underlining the high flexibility of $\beta$-(1,6)-D-glucan side chains, as previously reported in the literature (Manners et al., 1973; Stevens and Sathyanarayana, 1987; Kim et al., 2000). Among the other conformations such as random coil or densely-packed triple helix that can be found in the yeast cell wall, the single helix conformation evidenced for pure $\beta$-D-glucans could be proposed as the structure giving the highest potential sites for establishing an interaction with mycotoxins. Therefore, we investigated $\beta$-Dglucan single helix conformation for its complexing properties toward ZEN.

Macromolecular studies carried out in vitro with bound and free toxins in equilibrium here and there of a dialysis membrane indicated that chemical bonds are weak. Furthermore, environmental conditions such as $\mathrm{pH}$ and nature of the solvent altered the stability of the $\beta$-D-glucan structure, thus decreasing their
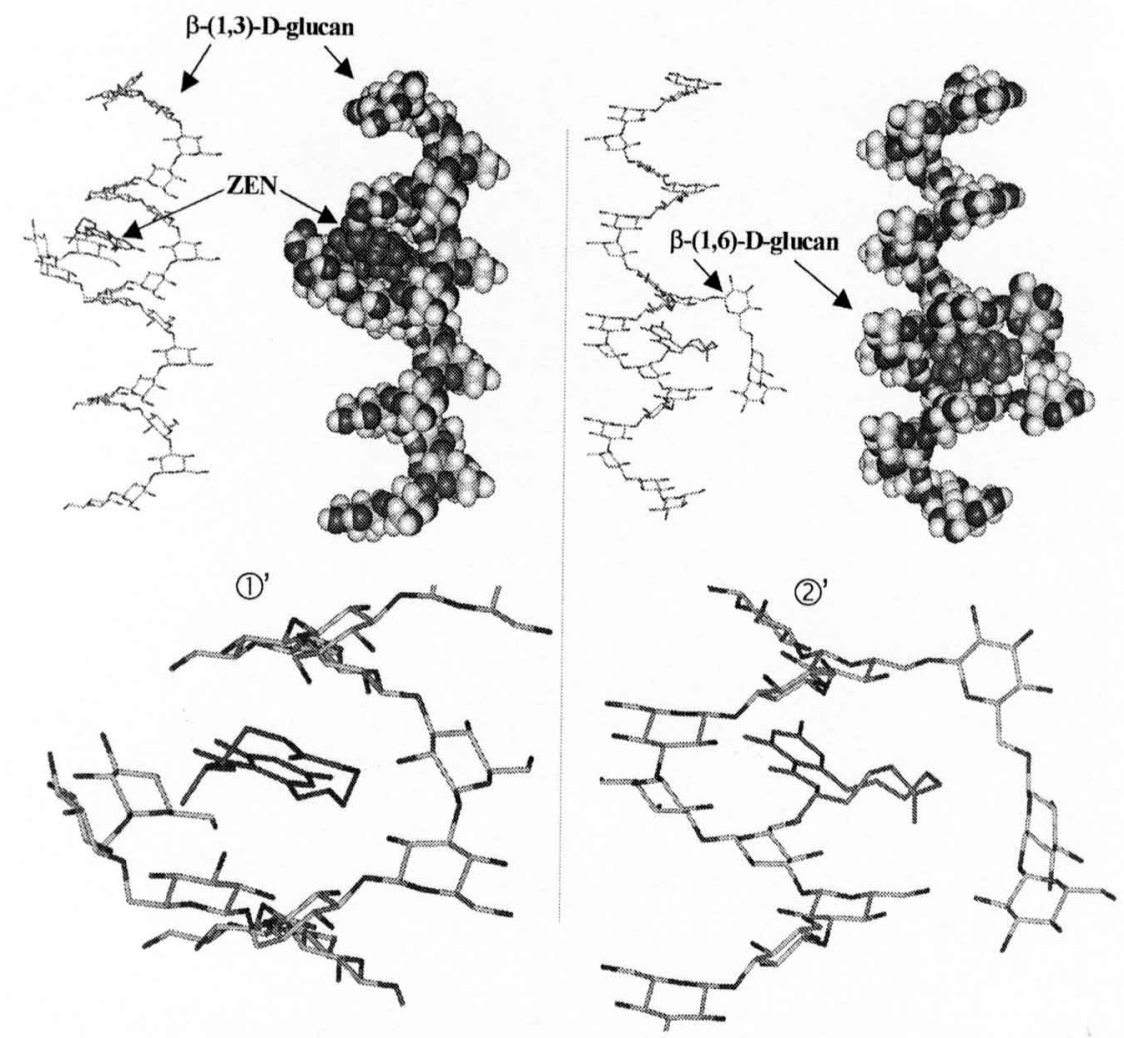

Figure 7. Computer-generated views (Insight II software) of the energy-minimized structure of the docking of the most favourable conformations in the single-helix of $\beta-(1,3)$-D-glucan chain branched with $\beta-(1,6)-\mathrm{D}$-glucan side chain. Two confirmations ((1)' and (2)') are presented 
ability to complex ZEN (Yiannikouris et al., 2003, 2004b,c,d). These results indicate that non-covalent bonds are involved in the interactions between $\beta$-Dglucans and ZEN, making them more "adsorption type" than "binding type".

${ }^{1} \mathrm{H}$ NMR investigations showed that the peaks of the two hydroxyl groups of ZEN phenol moiety were strongly reduced after reaction with $\beta$-D-glucans, which thus indicates that hydrogen bonds are implicated in the chemical interactions. Molecular mechanics showed that the $\beta$ - $(1,3)$-D-glucan chain promoted a very stable intra-helical association with ZEN (Figures 6,7). Two types of bonds were identified in the chemical association of ZEN and glucans: 1. hydrogen bonds involving hydroxyl, ketone and lactone groups of ZEN and hydroxyl groups of glucose unit in $\beta$-D-glucans; 2 . van der Waals bonds between $\beta$-D-glucopyranose rings and ZEN phenol moiety. The geometrical symmetry of ZEN molecule and the open site in the helix of $\beta$-D-glucans favors a close association between the two molecules. As a result, the ZEN molecule is totally trapped inside the $\beta$-Dglucan structure (Yiannikouris et al., 2004a).

Study of the chemical bonds involved in the interaction between $\beta$-D-glucans and aflatoxin B1, patulin and deoxynivalenol

The binding process of mycotoxins with $\beta$-D-glucans depends on the toxin. Using the molecular modeling technique, we defined the first molecular indices of the stability of binding for aflatoxin B1 (AFB1), patulin (PAT) and deoxynivalenol (DON). As indicated previously for ZEN, the geometry of AFB1 and ZEN molecules allows them to easily enter the open structures of the helical structure of $\beta$-D-glucans. The aromatic ring and the lactone group of AFB1 form polar or electron bonds with the glucose units in the single helix of $\beta$-D-glucans. The small size of PAT enables it to penetrate deep within the helix of $\beta-(1,3)$-D-glucans. Then, hydrogen bonds are formed between $\beta$-D-glucans and lactone and hydroxyl groups from PAT. Less geometrical similarities were found between the DON molecule and the single helix of $\beta$-D-glucans when compared to ZEN and AFB1 molecules, leading to a lower contribution of van der Waals bonds. However, DON was able to interact with $\beta(1,3)$-D-glucan molecule through at least two hydroxyl bonds.

We have identified for the first time the chemical mechanism of the interaction between mycotoxins and $\beta$-D-glucans at the molecular level. Although this study demonstrates the difficulty in extending our conclusions obtained on ZEN to all the mycotoxins, it indicates that certain chemical structures play a major role during the binding process with $\beta$-D-glucans. All aflatoxins, citrinin, ergotamine, T-2 toxin, paspalitrems, slaframine and verrucarin can probably bind to $\beta$-Dglucans due to their "aflatoxin-like", "deoxynivalenol-like" or "zearalenonelike" structures. For example, it has been reported that T-2 toxin has an affinity 
of about $33 \%$, as determined with a commercial product based on yeast cell wall according to Devegowda et al. (1998a,b).

\section{CONCLUSIONS}

This study underlines the major role played by $\beta$-D-glucans from yeast cell wall and their 3D-structure in the adsorption of ZEN. Interestingly, the geometrical, electrostatic and hydrophobic complementarities between a single helix of $\beta$-Dglucans and ZEN were identified as key factors in adsorption efficiency. As far as we know, this is the first study to elucidate how $\beta$-D-glucan chains have specific and quantitative complexing properties toward ZEN. The use of this organic material derived from yeast cell walls (Devegowda et al., 1998b; Newman, 2000; Dawson et al., 2001) could thus help to mitigate the harmful impact of mycotoxins on animals, and overcome the reduced bioavailability of some nutrients and their non-biodegradation in the environment.

Finally, we described an original in vitro method that can objectively discriminate yeasts according to their ability to adsorb a mycotoxin. We also elucidated the mechanisms involved in the formation of complexes between ZEN and yeast cell walls, and we proposed molecular models to describe the structures of the complexes formed in the digestive tract. The stability of complexes was also assessed. Electrostatic bonds between ZEN and yeast cell wall components were identified.

\section{ACKNOWLEDGMENTS}

This work was co-supported (CIFRE No. 704/2000) by Alltech Company, the ANRT (Association Nationale de la Recherche Technique) and the INRA French Research Institute .

We especially thank Drs. G. Jeminet and I. Canet (UMR-CNRS 6504, SEESIB, Université Blaise-Pascal Clermont II, Aubičre, France), Dr. J. François (UMR-CNRS 5504, UR-INRA 792, INSA Toulouse, France), Drs. L. Poughon and C.-G. Dussap (CUST, Université Blaise-Pascal Clermont II Aubičre, France), Dr. G. André (Institut Pasteur, Paris, France), Drs. A. Buléon and B. Pontoire (UR783 INRA, UPCM, Nantes, France), Dr. X. Cameleyre (Critt Bio-Industries, INSA, Toulouse, France), and Dr. P. Galtier (INRA-UR66, Toulouse, France) for their helpful collaboration. 


\section{REFERENCES}

CAST, 2003. Mycotoxins: Risks in Plant, Animal, and Human Systems. Council for Agricultural Science and Technology. In: K. Niyo (Editor). Task Force Report 139, Ames, Iowa (USA), pp. 1-199

Catley B.J., 1988. Isolation and analysis of cell walls. In: T. Campbell, J.H. Duffus (Editors). Yeast; a Practical Approach, Chapter 8, pp. 163-183

Chuah C.T., Sarko A., Deslandes Y., Marchessault R.H., 1983. Packing analysis of carbohydrates and polysaccharides. Part 14. Triple-helical crystalline structure of curdlan and paramylon hydrates. Macromolecules 16, 1375-1382

Cordier C., Gruselle M., Jaouen G., Hughes D.W., McGlinchey M.J., 1990. Structures of zearalenone and zearalanone in solution: a high-field NMR and molecular modelling study. Magn. Reson. Chem. 28, 835-845

Dallies N., François J., Paquet V., 1998. Yeast functional analysis reports: a new method for quantitative determination of polysaccharides in the yeast cell wall. Application to the cell wall defective mutants of Saccharomyces cerevisiae. Yeast 14, 1297-1306

Dawson K.A., Evans J., Kudupoje M., 2001. Understanding the adsorption characteristics of yeast cell wall preparations associated with mycotoxin binding. In: T.P. Lyons, K.A. Jacques (Editors). Science and Technology in the Feed Industry. Nottingham University Press, Nottingham (UK), pp. 169-181

Devegowda G., Raju M.V.L.N., Afzali N., Swamy H.V.L.N., 1998a. Mycotoxin picture world-wide: novel solutions for their counteraction. In: T.P. Lyons, K.A. Jacques (Editors). Biotechnology in the Feed Industry. Nottingham University Press, Nottingham (UK), pp. 241-256

Devegowda G., Raju M.V.L.N., Swamy H.V.L.N., 1998b. Mycotoxins: novel solutions for their counteraction. Feedstuffs 70 (50), 12-15

Diaz D.E., Hagler Jr. W.M., Hopkins B.A., Whitlow L.W., 2002. Aflatoxin binders I: in vitro binding assay for aflatoxin B1 by several potential sequestering agents. Mycopathologia 156, 223-226

Dvorska J., 2003. Aurofusarin, a newly described Fusarium graminearum mycotoxin: oxidative stress and protective effect of Mycosorb. In: T.P. Lyons, K.A. Jacques (Editors). Biotechnology in the Feed and Food Industry. Nottingham University Press, Nottingham (UK), pp. 93-106

Dvorska J.E., Surai P. F., 2001. Effects of T-2 toxin, zeolite and Mycosorb on antioxydant systems of growing quail. Asian-Austr. J. Anim. Sci. 14, 1752-1757

Dvorska J.E., Surai P.F., Speake B.K., Sparks N.H.C., 2003. Protective effect of modified glucomannans against aurofusarin-induced changes in quail egg and embryo. Comp. Biochem. Physiol. C 135, 337-343

Fleet G.H., 1991. Cell walls. In: A.H. Rose, J.S. Harrison (Editors). The Yeasts. Chapter 5. Academic Press, London, pp. 199-271

Freimund S., Sauter M., Rys P., 2003. Efficient adsorption of the mycotoxins zearalenone and T-2 toxin on a modified yeast glucan. J. Environ. Sci. Health B 38, 243-255

Galvano F., Piva A., Ritieni A., Galvano G., 2001. Dietary strategies to counteract the effects of mycotoxins: a review. J. Food Protect. 64, 120-131

Grant P.G., Phillips T.D., 1998. Isothermal adsorption of aflatoxin B1 on HSCAS clay. J. Agr. Food Chem. 46, 599-605

Guerre P., Bailly J.-D., Bernard G., Burgat V., 2000. Excrétion lactée des mycotoxines : quels risques pour le consommateur? Rev. Med. Vet. 151, 7-22

Huwig A., Freimund S., Käppeli O., Dulter H., 2001. Mycotoxin detoxification of animal feed by different adsorbents. Toxicol. Lett. 122, 179-188

Jemmali M., 1990. Decontamination and detoxification of mycotoxins. J. Environ. Pathol. Toxicol. Oncol. 10, 154-159 
Karlovsky P., 1999. Biological detoxification of fungal toxins and its use in plant breeding, feed and food production. Nat. Toxins 7, 1-23

Kim Y.-T., Kim E.-H., Cheong C., Williams D.L., Kim C.-W., Lim S.-T., 2000. Structural characterization of $\beta-(1,3)-, \beta-(1,6)$-linked glucans using NMR spectroscopy. Carbohyd. Res. $328,331-341$

Kogan G., 2000. Bioactive natural products (part D): $\beta$-(1,3)- and $\beta-(1,6)$-D-glucans of yeasts and fungi and their biological activity. In: Atta-ur-Rahman (Editor). Studies in Natural Products Chemistry. Elsevier Science B.V., Karachi (Pakistan), pp. 107-151

Kopecka M., Phaff H.J., Fleet G.H., 1974. Demonstration of a fibrillar component in the cell wall of the yeast Saccharomyces cerevisiae and its chemical nature. J. Cell Biol. 62, 66-76

Krishnamachari K.A., Bhat V. R., Nagarajan V., Tilak T.B., Tulpule P.G., 1977. The problem of aflatoxic human disease in parts of India-epidemiological and ecological aspects. Ann. Nutr. Aliment. 31, 991-996

Lee I.-Y., 2002. Curdlan. In: E. Vandamme, S. De Baets, A. Steinbüchel (Editors). Biopolymers. Vol. 5. Wiley, Hoboken, N.J. (USA), pp. 135-154

Lemke S.L., Ottinger S.E., Mayura K., Ake C.L., Pimpukdee K., Wang N., Phillips T.D., 2001. Development of a multi-tiered approach to the in vitro prescreening of clay-based enterosorbents. Anim. Feed Sci. Tech. 93, 17-29

Lipke P.N., Ovalle R., 1998. Cell wall architecture in yeast: new structure and new challenges. J. Bacteriol. 180, 3735-3740

Manners D.J., Masson A.J., Patterson J.C., Björndal H., Lindberg B., 1973. The structure of a $\beta$-(1,6)-D-glucan from yeast cell walls. Biochem. J. 135, 31-36

Marchessault R.H., Deslandes Y., 1979. Fine structure of $\beta$-(1,3)-D-glucans: curdlan and paramylon. Carbohyd. Res. 75, 231-242

Marchessault R.H., Deslandes Y., Ogawa K., Sundararajan P.R., 1977. X-Ray diffraction data for $\beta$-(1,3)-D-glucan. Can. J. Chem. 55, 300-303

Newman K., 2000. The biochemistry behind esterified glucomannans - titrating mycotoxins out of the diet. In: T.P. Lyons, K.A. Jacques (Editors). Biotechnology in the Feed Industry. Nottingham University Press, Nottingham (UK), pp. 369-382

Nuessli J., Putaux J.L., Bail P.L., Buleon A., 2003. Crystal structure of amylose complexes with small ligands. Int. J. Biol. Macromol. 33, 227-234

Pasikatan M.C., Dowell F.E., 2001. Sorting systems based on optical methods for detecting and removing seeds infested internally by insects or fungi: a review. Appl. Spectrosc. Rev. 36, 399-416

Patterson R., Young L.G., 1993. Efficacy of hydrated sodium calcium aluminosilicate, screening and dilution in reducing the effects of mold contaminated corn in pigs. Can. J. Anim. Sci. 73, 615-624

Pelosi L., 2002. Caractérisation des $\beta$-(1,3)-D-glucane synthases de Saprolegnia monoica et de leurs produits de synthčse, $\mathrm{PhD}$. Thesis, Université Joseph Fourier, Grenoble I, pp. 275

Pfohl-Leszkowicz A., 2000. Risques mycotoxicologiques pour la santé des animaux et de l'homme. Cah. Nutr. Diet. 35, 389-401

Pittet A., 1998. Natural occurrence of mycotoxins in foods and feeds - an update review. Rev. Med. Vet. 149, 479

Popolo L., Gilardelli D., Bonfante P., Vai M., 1997. Increase in chitin as an essential response to defects in assembly of cell wall polymers in the ggp1delta mutant of Saccharomyces cerevisiae. J. Bacteriol. 179, 463-469

Ramos A.J., Hernandez E., 1997. Prevention of aflatoxicosis in farm animals by means of hydrated sodium calcium aluminosilicate addition to feedstuffs: a review. Anim. Feed Sci. Tech. 65, $197-$ 206 
Schoental R., 1984. Mycotoxins and the bible. Perspect. Biol. Med. 28, 117-120

Schoental R., 1991. Mycotoxins, porphyrias and the decline of the Etruscans. J. Appl. Toxicol. 11, 453-454

Scott P.M., 1998. Industrial and farm detoxification processes for mycotoxins. Rev. Med. Vet. 149, 543-548

Smith T.K., MacDonald E.J., Haladi S., 2001. Current concepts in feed-borne mycotoxins and the potential for dietary prevention of mycotoxicoses. In: T.P. Lyons, K.A. Jacques (Editors). Science and Technology in the Feed Industry. Nottingham University Press, Nottingham (UK), pp. 183-189

Smith T.K., Swamy H.V.L.N, Raymond S.L., Zaytoun M., 2002. Contemporary protectives on Fusarium mycotoxicoses in livestock and poultry. In: T.P. Lyons, K.A. Jacques (Editors). Biotechnology in the Feed and Food Industry. Nottingham University Press, Nottingham (UK), pp. 373-378

Stevens E.S., Sathyanarayana B.K., 1987. Conformation of $\beta-(1,6)$-D-glucan by vacuum-ultraviolet circular dichroism. Carbohyd. Res. 160, 131-135

Surai P.F., Dvorska J.E., Sparks N.H.C., Jacques K.A., 2002. Impact of mycotoxins on the body's antioxidant defence. In: T.P. Lyons, K.A. Jacques (Editors). Biotechnology in the Feed and Food Industry. Nottingham University Press, Nottingham (UK), pp. 131-141

Swamy H.V.L.N., Smith T.K., Cotter P.F., Boermans H.J., Sefton A.E., 2002a. Effects of feeding blends of grains naturally contaminated with Fusarium mycotoxins on production and metabolism in broilers. Poultry Sci. 81, 966-975

Swamy H.V.L.N., Smith T.K., MacDonald E.J., Boermans H.J., Squires E.J., 2002b. Effects of feeding a blend of grains naturally contaminated with Fusarium mycotoxins on swine performance, brain regional neurochemistry, and serum chemistry and the efficacy of a polymeric glucomannan mycotoxin adsorbent. J. Anim. Sci. 80, 3257-3267

Whitlow L.W., Diaz D.E., Hopkins B.A., Hagler Jr. W.M., 2000. Mycotoxins and milk safety: the potential to block transfer to milk. In: T.P. Lyons, K.A. Jacques (Editors). Biotechnology in the Feed Industry. Nottingham University Press, Nottingham (UK), pp. 391-408

Whitlow L.W., Hagler W.M.J., 1999. An association of mycotoxins with production, health and reproduction in dairy cattle and guidelines for prevention and treatment. In: T.P. Lyons, K.A. Jacques (Editors). Biotechnology in the Feed Industry. Nottingham University Press, Nottingham (UK), pp. 401-419

Whitlow L.W., Hagler Jr. W.M., 2002. Mycotoxins in feeds. Feedstuffs 74 (28), 68-78

Yiannikouris A., André G., Buléon A., Jeminet G., Canet I., François J., Bertin G., Jouany J.-P., 2004a. Comprehensive conformational study of key interactions involved in zearalenone complexation with $\beta$-D-glucans. Biomacromolecules 5, 2176-2185

Yiannikouris A., François J., Poughon L., Dussap C.-G., Bertin G., Jeminet G., Jouany J.-P., 2004b. Adsorption of zearalenone by $\beta$-D-glucans in the Saccharomyces cerevisiae cell wall. J. Food Protect. 67, 1195-1200

Yiannikouris A., François J., Poughon L., Dussap C.-G., Bertin G., Jeminet G., Jouany J.-P., 2004c. Alkali-extraction of $\beta$-D-glucans from Saccharomyces cerevisiae cell wall and study of their adsorptive properties toward zearalenone. J. Agr. Food Chem. 52, 3666-3673

Yiannikouris A., François J., Poughon L., Dussap C.-G., Jeminet G., Bertin G., Jouany J.-P., 2004d. Influence of $\mathrm{pH}$ on complexing of model $\beta$-D-glucans with zearalenone. J. Food Protect. 2741-2746

Yiannikouris A., Jouany J.-P., 2002. Les mycotoxines dans les aliments des ruminants, leur devenir et leurs effets chez l'animal. INRA Prod. Anim. 15, 3-16

Yiannikouris A., Poughon L., Cameleyre X., Dussap C.-G., François J., Bertin G., Jouany J.-P., 2003. A novel technique to evaluate interactions between Saccharomyces cerevisiae cell wall and mycotoxins: application to zearalenone. Biotechnol. Lett. 25, 783-789 


\section{STRESZCZENIE}

Dlaczego składniki ściany komórkowej drożdży mogą zmniejszać niekorzystne działanie mykotoksyn na produkcję zwierzęcą i poprawiać bezpieczeństwo uzyskiwanych produktów spożywczych

Niektorzy autorzy podają, że dodanie ścian komórkowych drożdży do zanieczyszczonej paszy obniża szkodliwy wpływ mykotoksyn. Chemiczne podstawy interakcji między toksynami i wiążącymi je strukturami są jednak nieznane.

Wykazano, że $\beta$-D-glukany są tymi składnikami drożdży, które są odpowiedzialne za wiązanie (kompleksację) toksyn. Istotną rolę w efektywnym spełnianiu tej roli odgrywa siatkowa struktura utworzona przez $\beta$-D-glukany $i$ odpowiednie rozmieszczenie w niej $\beta$-(1,3)-D- i $\beta$-(1,6)-D-glukanów. W wiązanie toksyn przez $\beta$-D-glukany są również włączone słabe wiązania wodorowe i siły van der Waalsa, wskazując bardziej na „adsorpcyjny” niż „chemicznego wiązania” typ interakcji. W przedstawionej pracy dokonano molekularnego modelowania i obliczono potencjalny wydatek energii, celem określenia stabilności kompleksów. 